\title{
ПРОЦЕСНИЙ ПІДХІД В УДОСКОНАЛЕННІ ОРГАНІЗАЦІЙНОЇ СТРУКТУРИ УПРАВЛІННЯ БАНКОМ
}

\author{
ПРОЦЕССНЫЙ ПОДХОД В СОВЕРШЕНСТВОВАНИИ ОРГАНИЗАЦИОННОЙ \\ СТРУКТУРЫ УПРАВЛЕНИЯ БАНКОМ
}

\section{PROCESS APPROACH IN IMPROVING THE ORGANIZATIONAL STRUCTURE MANAGEMENT BANK}

\begin{abstract}
Обтрунтовано необхідність визначення $i$ нормативного закріплення статусу кредитних, клієнтських та депозитних підрозділів банку як «ризиковиків» або «продуктовиків», або продавиів продуктів. Доведено необхідність уточнення завдань $i$ відповідальності «розробників» $i$ «ризиковиків» у частині управління ризиками на відміну від компілювання розрізнених і не систематизованих інформаційних потоків. Запропоновано розиирення повноважень департаменту розвитку бізнесу шляхом декомпозиції його функцій між підрозділами з блоків «продажі» $i$ «продукти». Удосконалено варіант організаційної структури банку «Незалежність розвитку», щзо базується на адміністративному суверенітеті підрозділів, відповідальних за створення $і$ продажі продуктів. Розроблено науково-методичні положення щзодо обтрунтування вибору варіанту організаційної структури управління банком з виокремленням комплексу функціональних блоків, які відповідають за основні бізнес-прочеси. На початковому етапі функиіонування бізнесу запропоновано створення комітету з розвитку бізнесу у відповідному організаційному складi, з відповідними функиіями $і$ повноваженнями для підвищення ефективності та стандартизачії розвитку банку.
\end{abstract}

Ключові слова: банк, бізнес-процеси, департамент, організаційна структура, продукт, проектна група, управління

Обоснована необходиость определения $u$ нормативного закрепления статуса кредитных, клиентских и депозитных подразделений банка как “рисковиков» или «продуктовиков», или продавцов продуктов. Доказана необходимость уточнения задач и ответственности «разработчиков» и «рисковиков» в части управления рисками в отличие от компиляции разрозненных и не систематизированных информационных потоков. Предложено расширение полномочий департамента развития бизнеса путем декомпозиции его функиий между подразделениями из блоков «продажи» $u$ «продукть»». Усовершенствован вариант организачионной структуры банка «Независимость развития», основанный на административном суверенитете подразделений, ответственных за создание и продажи продуктов. Разработаны научно-методические положения по обоснованию выбора варианта организационной структуры управления банком с выделением комплекса функииональных блоков, отвечающих за основные бизнес-проиессы. На начальном этапе функиионирования бизнеса предложено создание комитета по развитию бизнеса в соответствующем организационном составе, с соответствующими 
функциями и полномочиями для повышения эффективности и стандартизации развития банка.

Ключевые слова: банк, бизнес-процессы, департамент, организационная структура, продукт, проектная группа, управление

The necessity of defining the status of regulatory consolidation and credit units, customer units and divisions of the bank deposit products as sellers. The necessity of clarifying tasks and responsibilities of units that deals with development of products in risk management. The author proposed to empower the Department of Business Development, by the decomposition of its functions between the departments of the units 'sale' and 'products'. Improved version of the organizational and functional structure of "Independence development", based on the sovereignty administrative units responsible for creating and selling products. The scientific-methodical provisions on justification of the choice option of the organizational structure of the bank management form the complex functional units responsible for key business processes. Initially, the operation of the business proposed creation of a committee of business development in the appropriate organizational structure, with the respective functions and powers to improve the efficiency and standardization of the bank.

Keywords: bank, business processes, department, organization structure, product design team, management

Вступ. У процесі управління банком вагома роль належить організаційній структурі. 3 їі допомогою структуруються і формалізуються підходи і методи управління, визначаються групи виконавців, розроблюються системи контролю і внутрішні взаємини, спрямовані на досягнення стратегічних цілей банку. Організаційна структура банку є тим основним елементом системи управління, що приводить у дію всі інші складові шляхом виконання об'єктами управління низки процесів (бізнес-процесів, процесів забезпечення та обслуговування), створення продуктів (послуг) і надання їх клієнтам. Від якості побудови організаційної структури (перш за все, це виражається в чисельності персоналу, розподілі виконуваних ними функцій i якості бізнес-процесів) залежить конкурентоспроможність і успіх банку в цілому.

Однак в дослідженнях організаційних структур управління банком не завжди розглядається інформаційна взаємодія ііі елементів, хоча вдосконалення руху інформаційних потоків $\epsilon$ важливим аспектом підвищення результативності системи управління. Іншим недоліком існуючих розробок в сфері організаційних структур управління банком $\epsilon$ оцінювання ефективності тільки на основі фінансових результатів. Частина досліджуваних питань управління розглянута лише в теоретичному аспекті, а пропоновані методики мало придатні для моделювання менеджменту банківської системи та кількісної оцінки ії ефективності. Внаслідок на зазначене, українським банкам доводиться самостійно вирішувати дану проблему, спираючись або на практичний досвід керівника, або на теоретичну базу, призначену для підприємств, без урахування специфіки функціонування банків, i, треба визнати, прийняті ними рішення не завжди виявляються вірними. 
Багато дослідників, які займалися удосконаленням організаційних структур управління, вказували на їх громіздкість і статичність, відсутність у них надійних розвинених зв'язків, перевантаження та неефективність інформаційних потоків. У ряду важливих робіт даного напрямку виділимо праці вітчизняних і зарубіжних учених В. Г. Герасимчука [1], Т. С. Смовженко [2], А. Бьерна [3], М. Мескона [4], Г. Мінцберга [5], В. Г. Еліферова [6], В. В. Рєпіна [7], М. Хаммера [8]. Попри вагомість висновків, сформульованих згаданими ученими, виникає необхідність внесення змін у процес формування й удосконалення організаційної структури управління банком, що, у свою чергу, вимагає подальшого розроблення методологічних $\mathrm{i}$ практичних положень у частині формування ефективної організаційної структури управління банком з урахуванням особливостей розвитку банківської системи України.

Постановка завдання. Мета дослідження: розвинути теоретичні, методологічні та методичні положення щодо удосконалення організаційної структури управління банком в умовах реформування вітчизняної банківської системи.

Методологія. Методологічну основу науково-практичного дослідження формують діалектичний метод наукового пізнання, фундаментальні положення теорії фінансів, стратегічного управління, концепції управління діяльністю банків, концептуальні підходи в економічній науці 3 вивчення проблем оптимізації організаційних структур фінансово-кредитних установ.

Результати дослідження. Банк, як і будь-яка інша бізнес-система, прагне виконати вимоги власників за рахунок задоволення потреб ринку i використовуючи наявні в розпорядженні ресурси й можливості. У такому разі саме керівники продуктових напрямів відіграють ключову роль, адже вони досконало знають і розуміють рушійні сили ринку, перспективи і тренди. Перед кожним керівником продуктового напряму стоїть завдання перетворення наявної в нього інформації про ринок у конкретну продуктову пропозицію.

Таким чином, усі керівники продуктових напрямів постійно створюють у системі стратегічного управління потік інформації про можливості та загрози, представленої в цифрах, концепціях нових продуктів і перспективних планах дій, тобто формують заявки на ресурси, що вкрай потрібні для успішної реалізації стратегії розвитку банку. 3 другого боку, зазначені заявки повинні порівнюватися 3 наявними в розпорядженні банку всіма видами ресурсів і його можливостями. Потік цих даних надходить від керівників функціональних підрозділів банку, що розпоряджаються ресурсами, і керуючих роботою регіональної мережі. Відповідальність за обробку даних, які надходять, зіставлення потреб ринку і можливостей банку, розроблення планів на всіх рівнях, порівняння їх з вимогами власників і підкріпленням бюджетами несуть підрозділи планування із залученням планово-бюджетних служб банку. 
Відмітимо, що розглянута послідовність дій здійснюється банком постійно на системній основі з виділенням конкретних підрозділів, які відповідають за перелічені дії. Зазвичай, ці підрозділи відносять до Департаменту стратегічного розвитку банку. Так, до участі у проектах розроблення і модифікації продуктів залучають фахівців багатьох функціональних підрозділів банку. Під кожен проект створюється тимчасовий організаційний підрозділ - група проекту, очолювана керівником відповідного продуктового напряму (рис. 1).

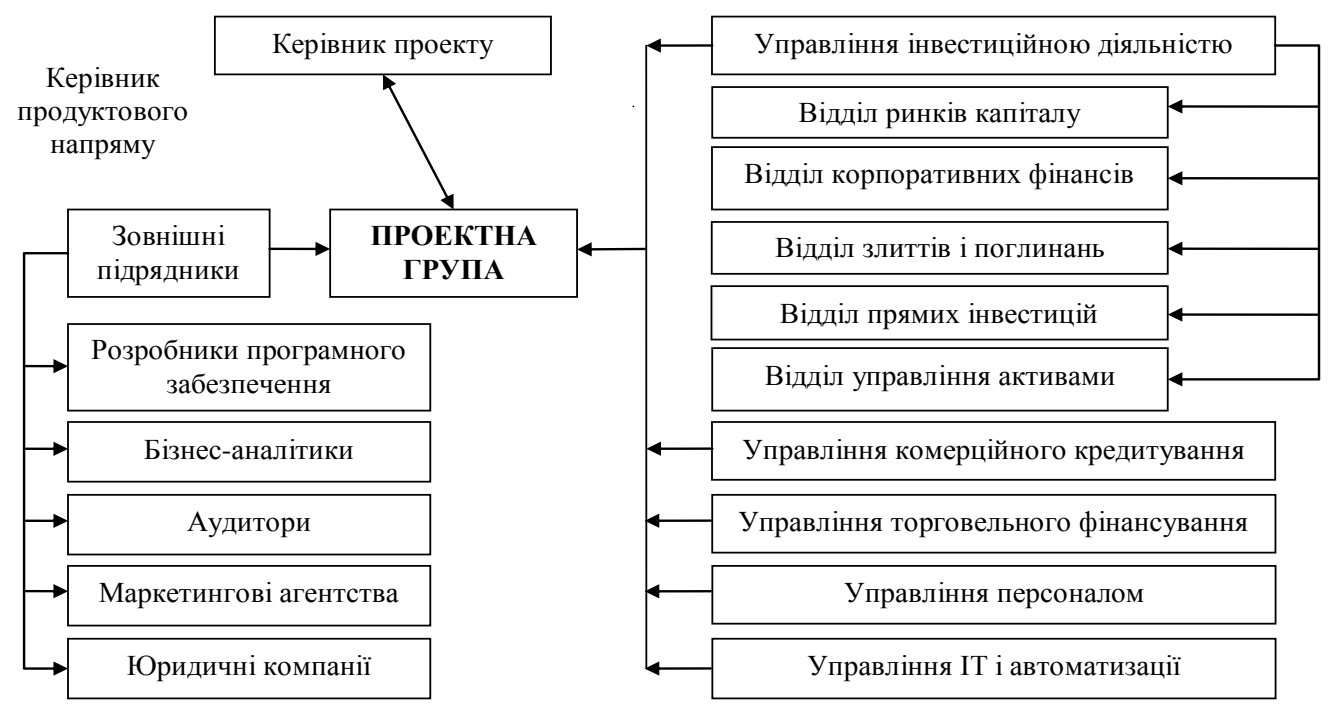

Рис. 1. Організаційна структура тимчасового підрозділу, очолювана керівником відповідного продуктового напряму Джерело: удосконалено автором на основі [9].

Окрім фахівців банку, до складу проектної групи можуть включати зовнішніх підрядників. Це дозволяє банку успішно управляти витратами, у той же час залучаючи більш кваліфікованих фахівців із профільних компаній. Зазначимо, що організацію проекту й управління він веде відповідно до прийнятих у банку принципів проектного управління. Як відомо, у кожному банку система управління продуктовим портфелем побудована 3 урахуванням притаманних тільки йому особливостей, але навіть при цьому зберігаються багато спільних ознак.

Істотні організаційні відмінності будуть між банками, які не мають виділеного корпоративного центру (невеликі банки без великої регіональної мережі), і банками, що здійснюють управління технологіями і стандартами 3 виділенням профільних підрозділів в окрему централізовану структуру, єдину для всієї своєї регіональної мережі (великі універсальні банки з розвиненою регіональною мережею) [10, с. 190].

Управління портфелем продуктів - складна і безперервна діяльність, що включає не тільки розроблення й опис сприйманих клієнтом характеристик продукту. Значні зусилля, час, бюджети доводиться витрачати на створення 
технологічної складової продукту. Однак ці зусилля варті того, оскільки саме ці складові визначають операційну перевагу банку над конкурентами, що стає вкрай необхідним у часи цінової конкуренції і насичених ринків. Банк, здатний вибудувати досконалі внутрішні процеси, не тільки забезпечить собі сильні конкурентні позиції в сьогоденні, а й надійні перспективи на майбутнє.

У складних економічних умовах для українських банків процес управління ризиками вимагає від керівництва і власників банку організації діяльності таким чином, щоб виникаючі конфлікти інтересів у персоналу і відділів банку були врегульовані на користь оптимального збереження ефективності банківського бізнесу. Один із серйозних ризиків діяльності банків - конфлікт інтересів творців продуктів, інтересів технологів продуктів та інтересів продавців продуктів [11, с. 243].

Технологи i методологи продуктів повинні бути відокремлені організаційно і функціонально (адміністративно) від продавців, інакше, якщо методологія входитиме в компетенцію продавців, то це неминуче призведе до утворення у продуктах елементів, які будуть збільшувати ризики банку в цілому. Так, продавці, бажаючи збільшити обсяги продажу продуктів, можуть закласти в його склад елементи без урахування податкових законів, які не тільки спричинять податкові претензії до клієнтів, а й власне до самого продавця продукту (банку).

Банкові потрібно конкретно визначити і нормативно закріпити статуси кредитних підрозділів банку [які супроводжують різні кредитні продукти корпоративне кредитування, споживчі кредити, векселі й інші боргові зобов'язання, міжбанківське кредитування (МБК)], клієнтських підрозділів, депозитних підрозділів як «ризиковиків» або «продуктовиків», або продавців продуктів. До речі, у діяльності банків, наприклад, «кредитники» (роздрібні і корпоративні), зазвичай, продавцями не $\epsilon$, а департаменти ресурсів (у складі відділів вексельних операцій та МБК) не є «ризик-менеджерами», і при цьому часто поєднують функції «продуктовиків» i «продавців». Продаж (у т. ч. i кредитних продуктів) здійснюється підрозділами роботи з клієнтами або навіть власне керівництвом банку. Втім, кредитні підрозділи, не беручи участі у продажах, слабо виконують роль технологів продуктів і ніяк не виконують функцію з управління ризиками. Крім того, затверджені і використовувані регламенти про кредитні підрозділи здебільшого мають формальний характер і на практиці не сприяють ефективній участі кредитних підрозділів в основній діяльності банку. Тут ідеться вже не лише про контроль якості бізнес-процесів і продуктів, а й про власне розроблення самих продуктів.

Вважаємо, що розв'язати проблему можна таким шляхом: конкретизувати завдання і відповідальність «розробників» $\mathrm{i}$ «ризиковиків» таким чином, щоб їхня діяльність торкалась управління ризиками, а не в компілюванні розрізнених і не систематизованих інформаційних потоків (громіздких форм 
звітності, які не узгоджуються, а іноді скопійованих із чужої банківської практики регламентів). Принаймні, на нашу думку, ефективним варіантом розв'язання проблем із розвитку бізнесу та 3 діяльністю в частині створення повного спектру продуктів у банку припускає надання статусу організатора розвитку бізнесу і технолога продуктів Департаменту розвитку бізнесу (ДРБ). Варто також конкретизувати функції ДРБ, тим більше, що такий підрозділ (управління або відділ розвитку бізнесу) вже існує в деяких банках і частково виконує функції з розвитку бізнесу і створення продуктів, методологічні i технологічні функції.

Удосконалена організаційна структура управління банком повинна сприяти без конфліктів інтересів i перепонів реалізувати послідовний функціональний ланцюг (ПФЛ), зміст якого полягає в тому, що «перші вигадують продукт, другі - створюють регламент і методику, треті - продають продукт, четверті - супроводжують, п’яті - перевіряють і т. д.». Власне кажучи, удосконалена організаційна структура банку повинна мати всі необхідні функціональні блоки для реалізації ПФЛ. Однак нині взаємодія, угруповання і склад функціональних блоків банку недостатньо забезпечують якісну реалізацію ПФЛ. Вважаємо, що для ефективної і якісної реалізації ланцюга ПФЛ у банку з усталеним і структурованим бізнесом слід використовувати розвинутий варіант організаційної структури банку, який ми пропонуємо назвати «Незалежність розвитку» (таблиця).

У такому варіанті доцільно сформувати функціональні блоки, які відповідатимуть за основні бізнес-процеси. Блоки радимо називати дирекцією. Дирекції складатимуться 3 департаментів, департаменти - 3 управлінь, управління - 3 відділів. Саме керівники дирекцій і повинні сформувати правління банку разом із головою правління і виконавчими директорами (керуючий директор, комерційний директор, фінансовий директор, технічний директор).

Таблиця

Розподіл функцій у запропонованій організаційній структурі управління банком (Департамент розвитку бізнесу у форматі «Незалежність розвитку»)

\begin{tabular}{|c|c|c|}
\hline \begin{tabular}{|c|} 
Дирекція \\
(Блок бізнес- \\
процесів)
\end{tabular} & Функції & $\begin{array}{r}\text { Структу } \\
\text { деп }\end{array}$ \\
\hline \begin{tabular}{|l} 
Продажі \\
(Фронт-офіс) \\
Департамент \\
розвитку \\
роздрібного \\
бізнесу
\end{tabular} & $\begin{array}{l}\text { Забезпечення виконання планів продажів } \\
\text { роздрібного бізнесу. Організація управління } \\
\text { продажами в мережі. Контроль і координація } \\
\text { роботи відділень та інших каналів продажів у } \\
\text { мережі. Проведення аналізу ринку й участь у } \\
\text { розробленні стратегії залучення клієнтів. } \\
\text { Розподіл планів продажів серед відлілень, }\end{array}$ & $\begin{array}{l}\text { Управління мережі продажів } \\
\text { [Відділ роздрібних продажів, Відділ } \\
\text { розвитку бізнесу філіальної мережі } \\
\text { (Група підтримки філіальної } \\
\text { мережі), } \\
\text { Відділ обслуговування клієнтів ГО]. } \\
\text { Управління розвитку роздрібного }\end{array}$ \\
\hline
\end{tabular}




\begin{tabular}{|c|c|c|}
\hline & $\begin{array}{l}\text { забезпечення і контроль виконання планів } \\
\text { продажів у розрізі продуктів, послуг, сервісів. } \\
\text { Забезпечення якісного кредитного портфеля і } \\
\text { портфеля пасивів, недопущення утворення } \\
\text { простроченої заборгованості за кредитами. } \\
\text { Здійснення аналізу ефективності роботи мережі, } \\
\text { винесення пропозицій про зміну організаційної } \\
\text { структури, збільшення (зменшення) штату, } \\
\text { оптимізації бізнес-процесів, процедур, } \\
\text { регламентів. Координація роботи мережі з } \\
\text { підрозділами ГО з метою виконання планів } \\
\text { продажів і поставлених завдань }\end{array}$ & $\begin{array}{l}\text { бізнесу [Call Center, Група продажів, } \\
\text { Група обслуговування і } \\
\text { консультування клієнтів, Група зі } \\
\text { збору простроченої заборгованості]. } \\
\text { Управління малого бізнесу } \\
\text { [Управляючі директори (Іванов I.I., } \\
\text { Сидоров В.І.), Відділ продаж } \\
\text { клієнтам малого бізнесу, Відділ } \\
\text { структурування угод] }\end{array}$ \\
\hline $\begin{array}{l}\text { Департамент } \\
\text { розвитку } \\
\text { корпоративно- } \\
\text { го } \\
\text { бізнесу }\end{array}$ & $\begin{array}{l}\text { Розроблення стратегії і побудова ефективної } \\
\text { системи продажів корпоративного бізнесу. } \\
\text { Розвиток корпоративного бізнесу, якісних і } \\
\text { кількісних показників клієнтської бази. } \\
\text { Розроблення стандартів залучення й } \\
\text { обслуговування корпоративних клієнтів. } \\
\text { Формування довгострокових відносин з } \\
\text { корпоративними клієнтами }\end{array}$ & $\begin{array}{l}\text { Управління по роботі з } \\
\text { корпоративними клієнтами } \\
\text { [Відділ по роботі з крупними } \\
\text { клієнтами, Відділ по роботі з } \\
\text { середніми клієнтами] }\end{array}$ \\
\hline $\begin{array}{l}\text { Продукти } \\
\text { Департамент } \\
\text { розвитку } \\
\text { роздрібного } \\
\text { бізнесу }\end{array}$ & $\begin{array}{l}\text { Ініціювання і участь у розробленні нових } \\
\text { продуктів, каналів просування і продажів, } \\
\text { програм навчання, системи мотивації. } \\
\text { Створення і супровід продуктів, моніторинг } \\
\text { якості і модернізація продуктів, маркетинг } \\
\text { (ринкові дослідження щодо попиту на } \\
\text { продукти) }\end{array}$ & $\begin{array}{l}\text { Управління розвитку роздрібного } \\
\text { бізнесу [Відділ розвитку продуктів, } \\
\text { Група пасивних продуктів, Група } \\
\text { кредитних продуктів, Група } \\
\text { пластикових карт, Група } \\
\text { моніторингу за якістю } \\
\text { обслуговування і підвищення } \\
\text { ефективності бізнес-процесів, Група } \\
\text { впровадження і розвитку СРМ } \\
\text { стратегії] }\end{array}$ \\
\hline $\begin{array}{l}\text { Департамент } \\
\text { розвитку } \\
\text { корпоративно- } \\
\text { го } \\
\text { бізнесу }\end{array}$ & $\begin{array}{l}\text { Розробка й організація роботи щодо просування } \\
\text { продуктів і послуг для корпоративних кліснтів }\end{array}$ & $\begin{array}{l}\text { Управління кредитних продуктів } \\
\text { [Відділ структурування угод, Відділ } \\
\text { документарних операцій і } \\
\text { торговельного фінансування, Відділ } \\
\text { банківських продуктів і методології } \\
\text { корпоративного бізнесу] }\end{array}$ \\
\hline \begin{tabular}{|l|} 
Управління \\
ризиками \\
(Мідл-офіс) \\
Департамент \\
контролю \\
банківських \\
ризиків
\end{tabular} & $\begin{array}{l}\text { Спостереження за діяльністю банку в рамках } \\
\text { лімітних ризиків, підтверджених з боку } \\
\text { Наглядової Ради і Правління. Забезпечення } \\
\text { визначення специфічних ризиків, вимір, } \\
\text { оцінювання й управління на одному рівні з } \\
\text { іншими функціями підтримки та спостереження } \\
\text { банку. Обговорення можливих ризиків і при } \\
\text { виникненні доведення до Наглядової Ради і } \\
\text { Комітету управління ризиками. Забезпечення } \\
\text { роботи системи, яка періодично доповідає про } \\
\text { управління ризиками в кожному відділі } \\
\text { операцій. Забезпечення загальної роботи у всіх } \\
\text { функціях управління ризиками в банку. Нагляд } \\
\text { за дотриманням встановлених лімітів для } \\
\text { кредитів у філіях. Нагляд за плануванням } \\
\text { моніторингів кредитів та за їх здійсненням. }\end{array}$ & $\begin{array}{l}\text { Управління кредитних ризиків } \\
\text { [Відділ роздрібного ризик- } \\
\text { менеджменту, } \\
\text { Відділ кредитних ризиків в } \\
\text { корпоративному бізнесі, Відділ } \\
\text { проблемних активів, } \\
\text { Служба аналізу ризиків (Відділ } \\
\text { ринкових і операційних ризиків, } \\
\text { Аналітичний відділ), Відділ } \\
\text { моніторингу банківських операцій]. } \\
\text { Управління контролю кредитних } \\
\text { угод [Відділ по роботі із заставним } \\
\text { майном, Відділ моніторингу } \\
\text { кредитних угод, } \\
\text { Відділ перевірки позичальників] }\end{array}$ \\
\hline
\end{tabular}




\begin{tabular}{|c|c|c|}
\hline & $\begin{array}{l}\text { Нагляд за виконанням усіх вимог, що } \\
\text { відносяться до всіх видів ризиків усередині } \\
\text { банківських правил і розпоряджень }\end{array}$ & \\
\hline $\begin{array}{l}\text { Економіка } \\
\text { Фінансовий } \\
\text { департамент }\end{array}$ & $\begin{array}{l}\text { Визначення фінансової політики банку, } \\
\text { розроблення і здійснення заходів щодо } \\
\text { забезпечення фінансової стійкості. Розроблення } \\
\text { і затвердження стратегії. Стратегічне } \\
\text { планування. Аналіз і прогнозування фінансово- } \\
\text { економічних показників. Формування } \\
\text { консолідованого бюджету. Формування } \\
\text { управлінської звітності. Керування діяльністю } \\
\text { фінансових підрозділів, організація роботи з } \\
\text { підвищення кваліфікації працівників, надання } \\
\text { методичної допомоги працівникам банку з } \\
\text { фінансових питань }\end{array}$ & $\begin{array}{l}\text { Фінансове управління [Відділ бізнес- } \\
\text { планування, Відділ звітності і } \\
\text { методології, Відділ бізнес-аналізу]. } \\
\text { Головний бухгалтер [Відділ з } \\
\text { податкового планування і операцій, } \\
\text { Центр зовнішньої звітності, } \\
\text { Бухгалтерський центр]. } \\
\text { Казначейство [Відділ управління } \\
\text { ліквідністю і валютними позиціями, } \\
\text { Відділ операцій на фінансових } \\
\text { ринках, Відділ інвестиційних } \\
\text { послуг] }\end{array}$ \\
\hline $\begin{array}{l}\text { (Бек-офіс) } \\
\text { Операційний } \\
\text { департамент }\end{array}$ & $\begin{array}{l}\text { Конвертація філій в операційні офіси. } \\
\text { Вибудовування загальних технологічних } \\
\text { процесів, спрямованих на оптимізацію } \\
\text { внутрішніх процедур і персоналу. Ведення } \\
\text { проектів спрямованих на отримання } \\
\text { додаткового непроцентного доходу. Ведення } \\
\text { проектів за централізацією функцій } \\
\text { підпорядкованих підрозділів. Нормування } \\
\text { робочого часу співробітників, участь у } \\
\text { створенні КПР } \\
\text { і системи мотивації для підпорядкованих } \\
\text { підрозділів і співробітників. Організація підбору } \\
\text { і навчання співробітників. Взаємодія із } \\
\text { суміжними підрозділами }\end{array}$ & $\begin{array}{l}\text { Операиійне управління [Відділ } \\
\text { супроводу банківських операцій } \\
\text { (Група оформлення пасивних } \\
\text { операцій, Група підтримки і } \\
\text { супроводу угод з ЦП), Відділ } \\
\text { касових операцій, Відділ } \\
\text { кореспондентських рахунків, } \\
\text { Головне сховище, Відділ } \\
\text { методології і контролю операційної } \\
\text { діяльності (Група з претензійної } \\
\text { роботи), Відділ архівування, Відділ } \\
\text { кредитного регістру]. Управління } \\
\text { оформлення кредитних угод [Відділ } \\
\text { оформлення угод з корпоративного } \\
\text { бізнесу, Відділ оформлення угод } 3 \\
\text { роздрібного бізнесу] }\end{array}$ \\
\hline $\begin{array}{l}\text { Технологї } \\
\text { i засоби } \\
\text { Департамент } \\
\text { IT і } \\
\text { автоматизації }\end{array}$ & $\begin{array}{l}\text { Розроблення IT-стратегії банку в частині IT- } \\
\text { інфраструктури: визначення ландшафту } \\
\text { апаратних і програмних платформ, архітектури і } \\
\text { розвитку систем обчислювальної } \\
\text { інфраструктури, систем зберігання даних і } \\
\text { резервного копіювання, локальних } \\
\text { обчислювальних мереж, мереж передачі даних і } \\
\text { телекомунікації }\end{array}$ & $\begin{array}{l}\text { Управління інформаційних } \\
\text { технологій [Відділ банківських } \\
\text { технологій, Відділ експлуатації } \\
\text { АВС, Відділ технічного } \\
\text { обслуговування] }\end{array}$ \\
\hline \begin{tabular}{|l} 
Безпека \\
Департамент \\
інформаційної \\
безпеки
\end{tabular} & $\begin{array}{l}\text { Економічна безпека і економічна розвідка. } \\
\text { Фізична охорона і супровід цінностей } \\
\text { (інкасація). Юридичний захист і супровід } \\
\text { основної діяльності банку. Інформаційна } \\
\text { безпека. Протидія легалізації злочинних } \\
\text { доходів. Документальні і камеральні ревізії і } \\
\text { контроль. Службові розслідування }\end{array}$ & $\begin{array}{l}\text { Управління безпеки [Інформаційно- } \\
\text { аналітичний відділ, Відділ режиму і } \\
\text { охорони, Відділ інформаційної } \\
\text { безпеки, Відділ реклами і зв'язків } 3 \\
\text { громадськістю (Група маркетингу)] }\end{array}$ \\
\hline
\end{tabular}

Джерело: розроблено автором на основі [12].

Керівниками дирекцій банку слід призначити менеджерів із числа персоналу банку. У запропонованому варіанті ДРБ не існує як самостійний підрозділ і його функції розподілені між підрозділами з блоків «продаж» i 
«продукти». Вважаємо, що адміністративна незалежність підрозділів, відповідальних за продаж, створення продуктів, керування ризиками, дозволить створювати продукти і формувати методики, що враховують усі аспекти діяльності банку, реалізувати ПФЛ з узгодженням інтересів усіх зацікавлених сторін.

Слід відмітити, що ДРБ доцільно розглядати в рамках усієї структури банку, оскільки ДРБ споживає продукти (функції) інших структурних підрозділів банку. Конкретна структура залежить від того, які стратегічні цілі стоять перед ДРБ - продаж уже готових продуктів, їхній супровід на ринку і аналіз їхньої ринкової позиції або ж розроблення і створення банківських продуктів, оцінка їх якості і споживчих характеристик. Якщо ДРБ - підрозділ «продажу», він має бути елементом дирекції (блоку) продажу, якщо підрозділ «продукти» - елементом дирекції (блоку) банківських продуктів. Така структура дасть змогу забезпечити організацію ефективної взаємодії підрозділів банку і максимально стандартизувати продукти і способи їх реалізації банком, а також уникнути стратегічних помилок, пов'язаних із відсутністю належного досвіду і кваліфікації з розвитку бізнесу в банку.

Зазначимо, що однією з головних умов забезпечення організаційної побудови має бути підпорядкування ДРБ безпосередньо одному з виконавчих директорів. Оптимальним варіантом може бути затвердження посади комерційного директора, який на рівні з керуючим директором, фінансовим директором, технічним директором безпосередньо б підпорядковувався раді директорів банку. При цьому всі виконавчі директори (керуючий директор, комерційний директор, фінансовий директор) не повинні втручатися в сферу відповідальності один одного в оперативному й у тактичному плані, крім випадків, визначених радою директорів і необхідністю дотримання загальної бізнес-стратегії банку [12]. У свою чергу, ДРБ має включати власні підрозділи продажу, продуктів, управління ризиками, економіки, технологій і засобів, бекофісу рівно в тій самій пропорції і в тій самій кількості, яка не порушить успішної взаємодії всіх підрозділів банку.

Згідно з нашими пропозиціями, ДРБ очолює директор департаменту, який і підзвітний комерційному директорові, котрий, у свою чергу, підзвітний раді директорів. Для цілей ефективності та стандартизації розвитку банку навіть на початковому етапі розвитку бізнесу доцільно створити комітет 3 розвитку бізнесу (КРБ) у складі і з повноваженнями, як це показано на рис. 2. 


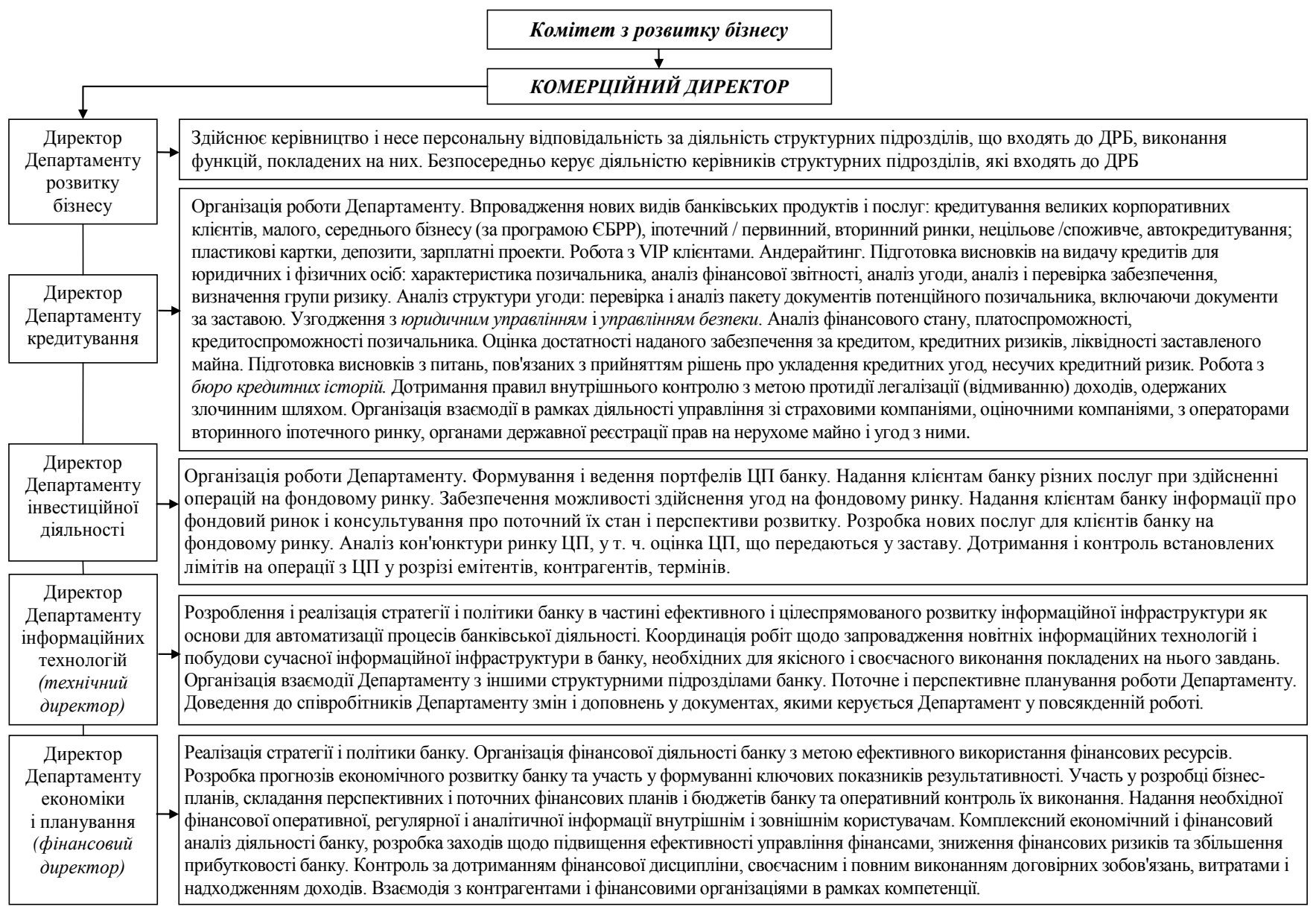

\section{Рис. 2. Організаційний склад, функції і повноваження комітету з розвитку бізнесу \\ Джерело: удосконалено автором на основі [12; 13].}

Запропонований нами варіант організаційної структури складено 3 розрахунку максимального урахування всіх можливих функцій банку. Так, ієрархію підрозділів наведено таким чином: дирекція - департамент управління - відділ. Якщо вищий рівень підрозділу передбачається, наприклад, у статусі департаменту, пропорційно повинні змінитися статуси підрозділів, згаданих у варіантах структур [департамент - управління - відділ - сектор (продукт)].

Департаменти управління ризиками, економіки, інформаційних технологій, безпеки (див. табл. 1) не слід включати до складу ДРБ, адже якість реалізації саме цих функцій істотно залежить від їх (департаментів) інтегрованості в загальний процес і незалежності від конкретних продуктів i бізнесу банку. Щоб успішно контролювати зазначені функції, досить створити у структурі ДРБ один підрозділ, який відповідав би за забезпечення цих функцій. У нашому варіанті, це може бути аналітичний відділ, до функцій якого можна включити: збір фінансової інформації про діяльність 
корпоративних клієнтів; аналіз фінансово-господарської діяльності позичальників - юридичних осіб і фінансової звітності; аналіз боргового портфеля, бізнес-плану, забезпечення за кредитним проектом; формування кредитної заявки на кредитний комітет; формування для профільних служб банку пакету документів для розкриття сутності кредитної операції і підготовки заявки для винесення на розгляд колегіального органу для прийняття рішення.

Викладений вище варіант побудови організаційної структури для розвитку бізнесу банку доречний при формуванні підрозділів роздрібного i корпоративного бізнесу з деякими коригуваннями на спеціалізацію. Наприклад, склад виконавчих директорів, що підпорядковані раді директорів, можна обмежити трьома посадами - керуючий директор, директор із роздрібного бізнесу, директор із корпоративного бізнесу. Решта керівників блоків (фінанси, ризики, технології, засоби) перебуватимуть у підпорядкуванні керуючого директора. Така організаційна структура в укрупненому варіанті застосовується в міжнародній практиці при побудові ТНБГ (Citigroup, HSBC, Deutsche Bank, Societe Generale, BNP Paribas) [14, c. 359].

Висновки. Запропоновано науково-методичні положення щодо обгрунтування вибору варіанту організаційної структури управління банком, що передбачає формування комплексу блоків, які відповідають за основні бізнес-процеси та дозволяють урегульовувати інтереси усіх зацікавлених сторін та реалізовувати послідовний функціональний ланцюг у частині створення та продажів повного спектру продуктів з наданням статусу організатора розвитку бізнесу департаменту розвитку бізнесу, функції якого розподілені між підрозділами з блоків «продажі» і «продукти». Такий варіант базується на адміністративному суверенітеті підрозділів, відповідальних за створення i продажі продуктів, управління ризиками та дозволяє уникнути помилок, пов'язаних з відсутністю певного досвіду реалізації стратегії розвиткубанку.

Запропоновані методичні та методологічні положення, що трансформовані в конкретні рекомендації, дозволяють значно підвищити рівень опрацювання стратегічних управлінських рішень у частині забезпечення високих показників стійкості фінансово-кредитних установ та ліквідності їх ресурсів, і тим самим зміцнити зайняті ними конкурентні позиції, що, в кінцевому рахунку, відповідає стратегічним економічним інтересам України.

Складні економічні умови висувають до банків нові якісні вимоги, в основі яких лежить фінансова стійкість їх функціонування. Оскільки надійність банку визначається не стільки розмірами активів, скільки якістю управління кредитно-інвестиційним портфелем, збалансованим 3 джерелами фінансових ресурсів банку, і кваліфікацією кадрів, тому одним з напрямків реформування банківської системи $є$ підвищення якості організаційної структури управління банком, покликаної забезпечити повсякденну, цілеспрямовану діяльність банку і його персоналу. 
Перспективи подальших наукових розробок пов'язані 3 нагальною необхідністю наукового аналізу й узагальнення позитивного міжнародного досвіду в сфері управління банківською діяльністю. При цьому розроблені в розвинених країнах технології фінансового менеджменту повинні бути критично переосмислені з урахуванням української економічної дійсності.

\section{Література:}

1. Герасимчук В. Г. Управление организацией : функциональный подход / В. Г. Герасимчук // Економічний вісник НТУУ «Київський політехнічний інститут» : Зб. наук. праць. - К. : Вид-во НТУУ «КПІ», ВПІ ВПК «Політехніка», 2014(11). - С. 255262.

2. Смовженко Т. С. Антикризове управління стратегічним розвитком банку : монографія / Т. С. Смовженко, О. М. Тридід, В. Я. Вовк ; Нац. банк України. Ун-т банк. справи. - К., 2008. $-473 \mathrm{c}$.

3. Андерсен Бьерн. Бизнес-процессы. Инструменты совершенствования / Бьерн Андерсен ; пер. с англ. С. В. Ариничева ; науч. ред. Ю. П. Адлер. - М. : РИА «Стандарты и качество», 2003. $-272 \mathrm{c}$.

4. Мескон М. Основы менеджмента / М. Мескон, М. Альберт, Ф. Хедоури ; пер. с англ. 3-е изд. - М. : Вильямс, 2007. -672 с.

5. Минцберг Г. Стратегический процесс. Концепции, проблемы, решения / Г. Минцберг, Дж. Б. Куинн, С. Гошал ; пер. с англ. - СПб. : Питер, 2001, - 688 с.

6. Елиферов В. Г. Бизнес-процессы : Регламентация и управление / В. Г. Елиферов, В. В. Репин : учебник. - М. : ИНФРА-М, 2005. - 319 c.

7. Репин В. В. Процессный подход к управлению. Моделирование бизнес-процессов / В. Г. Елиферов, В. В. Репин. - М. : РИА «Стандарты и качество», 2004. - 408 с.

8. Хаммер М. Реинжиниринг корпорации : Манифест революции в бизнесе / М. Хаммер, Дж. Чампи ; пер. с англ. - М. : Манн : Иванов и Фербер, 2006. - 287 с.

9. Борисов А. Финансовый продукт. Организационные основы. Примеры организационной реализации [Электронный ресурс] / А. Борисов. - 05.02.2008. - Режим доступа : http://bankir.ru/tehnologii/s/elementi-sistemi-strategicheskogo-ypravleniya-vbankah-okonchanie-1374430.

10. Морсман Э. М. (мл.). Управление кредитным портфелем / Э. М. Морсман-мл. ; науч. ред. В. Ионов ; пер с англ. М. Даниэль. - М. : Альпина Бизнес Букс, $2004-208$ с.

11. Поморина М. А. Планирование как основа управления деятельностью банка / М. А. Поморина. - М. : Финансы и статистика, 2002. - 384 с.

12. Исьемин А. Организационные структуры растущего банка, или Эффективное управление современным розничным банком-2 [Электронный ресурс] / А. Исьемин. 03.10.2005. - Режим доступа : http://bankir.ru/tehnologii/s/organizacionnie-stryktyrirastyschego-banka-ili-effektivnoe-ypravlenie-sovremennim-roznichnim-bankom-2-1380728.

13. Исьемин А. Эффективное управление современным розничным банком [Электронный pecypc] / A. Исьемин. - 13.05.2004. - Режим доступа : http://bankir.ru/tehnologii/s/effektivnoe-ypravlenie-sovremennim-roznichnim-bankom1380599.

14. Ларионова И. В. Риск-менеджмент в коммерческом банке : монография / кол. авт. ; под ред. И. В. Ларионовой. - М. : КноРус, 2014. - 456 с. 